\title{
Evaluation of the Economic Development Potential of Harbor Industrial District in Zhejiang Province
}

\author{
CHEN Pei-xiong \\ Ocean Engineering Institute \\ The Second Institute of Oceanography, SOA \\ Hangzhou, China \\ ZHANG He \\ Ocean Engineering Institute \\ The Second Institute of Oceanography, SOA \\ Hangzhou, China
}

\author{
WANG Qi \\ Business Department \\ Marine Monitoring and Forecasting Center of Zhejiang \\ province \\ Hangzhou, China
}

\author{
LI Zhi-bin \\ Ocean Institute \\ Zhejiang Sci-tech University \\ Hangzhou, China
}

\author{
FANG Ruo-zhou \\ Ocean Institute \\ Zhejiang University \\ Hangzhou, China
}

\begin{abstract}
Harbor industrial district has been the key to the development of the world and China's coastal developed regions for a long time. The economic development of harbor industrial district in a city plays a very important role in promoting the economic development of the city. In order to summarize the indicator system of the evaluation of the growth potential of harbor industrial district, this paper selects the harbor industrial district in Zhejiang province as an example by using the method of principal component analysis to evaluate with the factors of port conditions, economic and technological conditions, social infrastructure and external linkage, and selects 11 socio-economic indicators that are related to the above factors which can show the regional characteristics and regional differences. Meanwhile, by using analytic hierarchy process, the potential of each harbor industrial district is comparatively analyzed. Through analysis, the weight of each indicator is obtained. Then we score the overall development potential of each harbor industrial district to comprehensively evaluate the growth potential of harbor industrial district in Zhejiang province and put forward some suggestions. This research that is based on the national recognition of harbor industrial development and focuses on the sustainable development of harbor industry in the future has an important significance for the development of harbor industrial district.
\end{abstract}

Keywords-harbor industrial district; growth potential; evaluation system; sustainable development

\section{INTRODUCTION}

Harbor industry relies on the port resources and the port related advantages. In order to reduce costs to the most extent and enhance the competitiveness of enterprises, it takes the port into a part of the industrial production line.
Harbor industrial district is a new input and large output industrial organization system, which takes the coastal area and the port as the core, the port industrial cluster and the strip development as the basis, and the export-oriented economy and large scale as the typical characteristics [1].

With the development of Marine economy, Harbor industrial district has gradually become the key factor to promote the economic development of the world as well as the coastal developed areas in China. The potential evaluation of the port industrial area can not only provide the policy guidance for the government, but also promote the division of labor, cooperation and layout optimization of the harbor industrial district.

\section{MAIN CONTENTS OF THE EVALUATION}

The influencing factor which not only can show the comprehensive conditions of the harbor industrial but also consistent with the evaluation objectives of the development potential of harbor industrial district is the base and key point to evaluate the development potential.

The evaluation research of the development potential of harbor industrial district is to provide reference for the government to develop planning and layout for the harbor industry, as well as the industrial development policy and strategic decision. It is the main theoretical basis of industrial structure optimization research in harbor industrial district. The purpose of this study is to discuss the development potential of the industrial district based on the present developing situation of the harbor industrial district and the existing conditions.

The remainder of the paper is organized as follows: The next section uses the method of principal component analysis to analyze and establish the indicator system of the potential 
evaluation of harbor industrial district from the aspects of infrastructure, economic base and port condition. In Section 4, by means of analytic hierarchy process, the indicator system of the potential evaluation is analyzed, and the scores on corresponding indicators are obtained. Finally, the evaluation results are obtained from the comparison of each harbor industrial district.

\section{EVAluAtion METHODS OF THE DEVELOPMENT POTENTIAL OF HARBOR INDUSTRIAL DISTRICT}

The evaluation process mainly includes two aspects. One is to use the principal component analysis to establish the indicator system of the potential evaluation of the harbor industrial district and select a series of variables which can replace these complex variables and contain most of the information. Notably, these numbers of variables should be relatively small in order to analyze easily.

The other one is a comparative analysis on the potential of the harbor industrial district by using the analytic hierarchy process. Through analysis, we obtain the weight of each indicator.

Then through the score assignment, it finally comes to the total weight of each development potential of harbor industrial district, so as to quantitatively analyze the development potential of each harbor industrial district.

\section{A. Principal component analysis}

Principal component analysis (PCA) is a statistical procedure that uses an orthogonal transformation to convert a set of observations of possibly correlated variables into a set of values of linearly uncorrelated variables called principal components. The number of distinct principal components is equal to the smaller of the number of original variables or the number of observations minus one. In recent years, this method has been paid more and more attention and has gradually become a unique multi-indicator evaluation technique.

We suppose there are n numbers of objects, and each object has P indicators: X1,X2....XP. These indicators are compared among $n$ objects, thus there are nxp numbers of data. The initial goal of principal component analysis is to transform these original indicators into new and independent comprehensive indicators: Y1,Y2...YP. These comprehensive indicators represent linear functions of the original

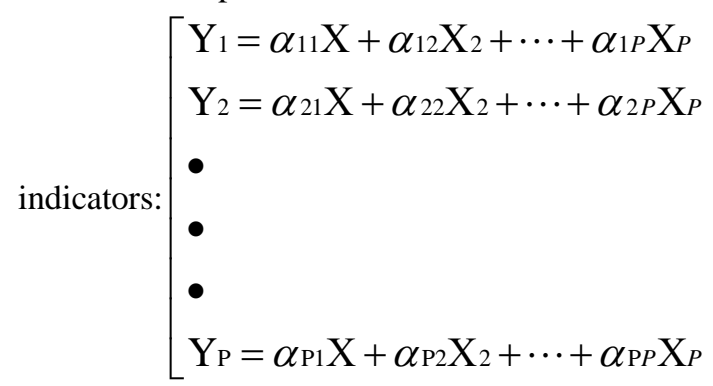

In shorthand: $\mathrm{Y}_{i}=\sum a_{i j} \mathrm{X}_{j}(\mathrm{i}, j=1,2 \ldots p)$

In formula (1), the indicator $\mathrm{Yi}$ is not related to each other. Because each indicator $\mathrm{Y}$ is a linear combination of the original indicators, and it is a new indicator. In fact, the principal component analysis is to decompose the total variance of all the original indicators into the sum of the variance of P uncorrelated composite indicators. Moreover, the variance of the first comprehensive indicator $\mathrm{Y} 1$ is the maximum. The second comprehensive indicator $\mathrm{Y} 2$ is the second largest variance, and so on. Generally, the first few comprehensive indicators can include most of the information of the total variance. We call them the first, the second, and...the $r$ th principal component. Namely, the principal component analysis can make most of the variance of the original indicators concentrated on a few principal components. Through the analysis of these principal components, the comprehensive evaluation of the whole is realized.

\section{B. Analytic hierarchy process}

The analytic hierarchy process (HP) is a structured technique for organizing and analyzing complex decisions, based on mathematics and psychology. It was developed by Thomas L. Saaty in the 1970s and has been extensively studied and refined since then.

Users of the AHP first decompose their decision problem into a hierarchy of more easily comprehended sub-problems, each of which can be analyzed independently. Once the hierarchy is built, the decision makers systematically evaluate its various elements by comparing them to each other two at a time, with respect to their impact on an element above them in the hierarchy. In making the comparisons, the decision makers can use concrete data about the elements, but they typically use their judgments about the elements' relative meaning and importance. It is the essence of the AHP that human judgments, and not just the underlying information, can be used in performing the evaluations.

It can be roughly divided into three steps as follows: The first step is to analyze the relationship among the various factors in the system and compare the importance of each element in the same level with a certain criterion in the previous level so as to construct a comparison matrix. The second step is to calculate the relative weight of the criterion by the matrix and check the consistency of the judgment matrix. The last step is to calculate the total order weight of the system and rank it.

The most important part of AHP is to determine the weight of each indicator. It usually adopts a three-level set of indicators to establish a hierarchical model of determining factors and evaluating indicators, namely, the target layer A, the criterion layer $B$, the index layer $C$ and their relation. Finally, we establish the index level and carry on the weight.

The steps to determine the weight are as follows.

Step 1: score the criterion layer and obtain the weight of each indicator

Step 2: score the index layer and obtain the weight of each indicator.

Step 3: use the weight of the criterion layer to multiply the corresponding index layer at corresponding echelon, and get the final weight set of each indicator.

It has particular application in group decision making, and is used around the world in a wide variety of decision 
situations, in fields such as government, business, industry, healthcare, shipbuilding and education.

\section{ANALYSIS OF FACTORS INFLUENCING THE}

DEVELOPMENT POTENTIAL OF HARBOR INDUSTRIAL DISTRICT

\section{A. Determination of influencing factors of development potential}

The development potential of harbor industrial district is the ability that promotes the sustainable development of harbor industry in certain areas and certain elements of the stimulus. Whether the specific industrial region has the potential ability for sustainable development in the future and the size of this capacity determines the development trend of the harbor industry to a certain degree. To effectively excavate and enhance this potential ability depends on the correct and objective evaluation.

According to the characteristics of the internal and external environment of harbor industrial district, the development of harbor industrial districts are influenced by the port conditions, the economic strength of the city where it locates, natural conditions, policy environment, infrastructure, transportation system, management service level and other factors.

However, the assessment of the development potential of harbor industrial district is still at an initial stage and the construction of its indicator system has not yet been unified. Therefore, this study is based on the theoretical results of the synthetic research on potential and the opinions of experts and scholars, finally, the evaluation factors are as follows: (1port condition; (2) technic-economical condition; (3) social infrastructure; (4)external linkage.

According to the actual situation of Zhejiang province, 11 socio-economic indicators (Table I) which are related to the above factors and can show regional characteristics and regional differences are selected. Through principal component analysis, the indicator system of the development potential of harbor industrial district is concluded

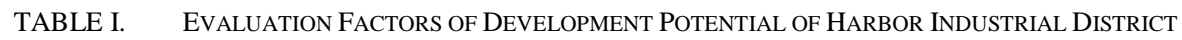

\begin{tabular}{|l|l|}
\hline \multicolumn{1}{|c|}{ First class index } & \multicolumn{1}{c|}{ Second class index } \\
\hline Port condition & $\begin{array}{l}\text { Port cargo throughput; } \\
\text { Length of port shoreline. }\end{array}$ \\
\hline \multirow{3}{*}{ Technic-economical condition } & $\begin{array}{l}\text { Real GDP per capita; } \\
\text { Value of industrial output; } \\
\text { Industry power consumption; } \\
\text { Number of technical personnel. }\end{array}$ \\
\hline \multirow{3}{*}{ Social infrastructure } & $\begin{array}{l}\text { Fixed assets investment above the limit; } \\
\text { Number of management personnel of water conservancy, environment and public } \\
\text { facilities; } \\
\text { Cargo volume. }\end{array}$ \\
\hline External linkage & $\begin{array}{l}\text { Total exports (\$100 million); } \\
\text { The actual use of foreign investment. }\end{array}$ \\
\hline
\end{tabular}

\section{B. Analysis of influencing factors of development potential}

This study uses SPASS16.0 to analyze the original data with principal component analysis, and attempts to obtain several core influencing factors for the evaluation of the development potential of harbor industrial district. First, we treat the original data with un-dimensioned process, so as to avoid the influence caused by the difference of statistical units and the excessive disparity of data. Then a 4 (sample) x 11 (indicators) matrix ( Table I) is analyzed with principal component analysis. 3 common factors are selected according to the principle that the feature root is greater than 1 , and the cumulative variance contribution rate is $95.29 \%$. At the same time, for the convenience of interpretation, the original variable load matrix is transformed by orthogonal rotation with variance maximization, and the factor load matrix table is obtained ( as shown in Table II).

The table shows that the first factor contribution rate is $67.97 \%$, which shows the information more comprehensive. The variables of factor load are the total amount of actual utilization of foreign investment, real GDP per capita, fixed assets investment above the limit, the number of management personnel of water conservancy, environment and public facilities, total exports and industry power consumption. In general, more than $50 \%$ of the variables can be explained by infrastructure investment, so this study explains this factor using infrastructure conditions.

The second factor contribution rate is $17.68 \%$, considering that it is positively correlated with other variables, and the higher factor load variables are the freight volume and industrial output value, so we think that the economic base condition of the local city can explain this factor.

The explanation effect of the third factor is obvious, the factor contribution rate is $9.64 \%$, and the higher factor load is the length of port shoreline and port cargo throughput, 0.986 and 0.726 , respectively. This article uses the port condition to explain this factor.

Therefore, it is feasible to evaluate the development potential of harbor industrial district from three aspects: infrastructure conditions, economic basic conditions and port conditions. 
TABLE II. FACTOR LOAD MATRIX

\begin{tabular}{|c|c|c|c|}
\hline Independent variable & $\begin{array}{r}\text { First } \\
\text { factor }\end{array}$ & $\begin{array}{l}\text { Second } \\
\text { factor }\end{array}$ & $\begin{array}{r}\text { Third } \\
\text { factor }\end{array}$ \\
\hline Total amount of actual utilization of foreign investment & 0.927 & & \\
\hline Real GDP per capita(Yuan) & 0.860 & & \\
\hline Fixed assets investment above the limit(100 million yuan) & 0.775 & & \\
\hline $\begin{array}{l}\text { The number of management personnel of water conservancy, environment and public facilities(Ten thousand } \\
\text { people) }\end{array}$ & 0.773 & & \\
\hline Total exports(Hundreds of millions of dollars) & 0.745 & & \\
\hline Industry power consumption & 0.700 & & \\
\hline Freight volume(Ten thousand tons) & & 0.872 & \\
\hline Industrial output value & & 0.802 & \\
\hline Number of technical personnel & & 0.777 & \\
\hline Length of port shoreline(Km) & & & 0.986 \\
\hline port cargo throughput(Ten thousand tons) & & & 0.716 \\
\hline Characteristic root & 8.157 & 2.122 & 1.156 \\
\hline Contribution rate & 67.973 & 17.684 & 9.635 \\
\hline Accumulative contribution rate & 67.973 & 85.657 & 95.291 \\
\hline
\end{tabular}

\section{V.THE CONSTRUCTION OF DEVELOPMENT POTENTIAL} EVALUATION INDEX SYSTEM OF HARBOR INDUSTRIAL DISTRICT

\section{A. The construction principles of evaluation index system}

The development potential evaluation system of harbor industrial district is a comprehensive system multiple factors. As a complicated system evaluation process, there are many evaluation indexes and factors involved in the system. Harbor condition, economic base and infrastructure should be considered comprehensively. The establishment of the index system is also not the simple list of the characteristics of study object. Its choice should follow certain principles. According to the main content of harbor industrial district development potential evaluation, the establishment of evaluation index should follow the principles:

\section{1) Comprehensiveness and Systematicness}

Index system can show the related content in every aspects of harbor industrial district development potential fully, and there is enough coverage. Index system should not only consider the factors of natural and social, but also avoid the overlap between indicators. So that, the evaluation target and evaluation Index can constitute a Hierarchical organic whole with the target layer, criterion layer and index layer.

\section{2) Representativeness and Conciseness}

The selection of indicators should emphasize the typicality and representative, and avoid choosing the derived index of similar meaning, repetitive or which can be combined by the other indicators. At the same time, the selected index should be relatively simple and easy to use.

\section{3) Feasibility and Operability}

The construction of index system is often based on the theoretical analysis, but in practice is often restricted by the source of datum greatly. Therefore, the selected index should be based on a certain statistical data and have clear meaning so that the index is more exercisable and credible.

4) The combination of qualitative indexes and quantitative indexes

The method of combining the qualitative indexes and quantitative indexes, can reduce the lack in conviction due to the pure qualitative index, the errors and incomplete phenomenon of the pure quantitative index due to the lack of data support, thus improve objectivity of evaluation result.

\section{$B$. The construction of evaluation index system}

Through the analysis of the factors influencing the development potential evaluation of harbor industrial district, the three core conditions constituting the evaluation of the potential development of harbor industrial district is infrastructure condition, economic basis condition and harbor condition. Because the information of index is too indistinct, the index needs to be further decomposition in order to facilitate further analysis. In terms of infrastructure condition, including the transportation networks, the regional water supply capacity and the fixed-asset investment level. Economic basis condition mainly includes the economic development level, supporting service level, talent service levels, and foreign trade level. The main factors of harbor condition include the harbor capacity, conditions of harbor construction and harbor reserve land (Table III).

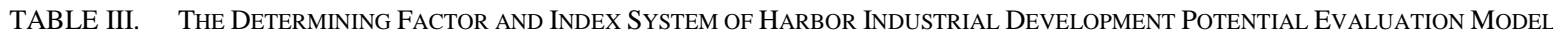

\begin{tabular}{|c|c|c|}
\hline & First indexes & Secondary index \\
\hline \multirow{10}{*}{$\begin{array}{lr}\begin{array}{l}\text { Harbor industrial district } \\
\text { development }\end{array} \text { potential } \\
\text { evaluation index system }\end{array}$} & \multirow{3}{*}{ Infrastructure condition } & Transportation networks \\
\hline & & Regional water supply capacity \\
\hline & & The fixed-asset investment level \\
\hline & \multirow{4}{*}{ Economic basis condition } & Economic development level \\
\hline & & Supporting service level \\
\hline & & Talent service levels \\
\hline & & Foreign trade level \\
\hline & \multirow{3}{*}{ Harbor condition } & Harbor capacity \\
\hline & & Harbor construction condition \\
\hline & & Harbor reserve land condition \\
\hline
\end{tabular}




\section{1) Infrastructure condition}

Infrastructure conditions, as an important factor of reflect the harbor industrial district development potential, mainly through three indexes to measure: transportation networks, regional water supply capacity and the fixed-asset investment level.

The industrial age, a transport links between the elements within the region, is the main way to make the connection between economic activities in a geographic space. Economic development potential and regional traffic conditions are closely related in much degree, the index to show the regional traffic conditions is transportation network. The core of Transportation network is harbor. It bears the function of cargo transportation between harbors and their cities and hinterland, by the supporting, cohesion and coordination of land, sea, air, pipeline and other important mode of transportation. So the transportation network becomes rigid index of harbor industrial rapid development in the future. the industry of harbor industrial district is main the heavy industry, energy, paper making and so on, the industry of big energy consumption, big water consumption, big large transportation capacity all around the world. So the regional water supply capacity must be factors to measure the development potential of harbor industrial district. Regional water supply capacity is reflected by areas daily water supply. The fixed-asset investment level is the most direct measure index of harbor industrial district in the infrastructure condition factors, which mainly is reflected by fixed-asset investment above limitation.

\section{2) Economic basis condition}

Economic basis condition occupies a very important position in the comprehensive evaluation of development potential of harbor industrial district. Its content includes four aspects: economic development level, supporting service level, talent service levels and foreign trade level.

Economic development level is the important factor to determine the development of harbor industrial district. The industrial progress relies on the rapid development of area economy and the dramatic growth of foreign trade in many ways. We can say that the economic developed area, its industry and trade must be developed. Therefore, the level of economic development should be an important index in the system. At the same time, the development of industry also relies on the convenient supporting service conditions. Here, the index to measure the main supporting service level is the proportion of the tertiary industry. In the tertiary industry, the normal operation of public finance, finance, municipal administration and communications is a precondition for the normal operation of industrial district, are also the important factors to determine the regional advantages of industrial district. Talent is the propellant of economic development, a good talent service levels is a prerequisite for rapid economic development. This article mainly uses the number of personnel engaged in science and technology activities to show talent service level. As a harbor industrial district, the best index to show its economic vitality is the foreign trade level. We use the total amount of foreign trade as the measure of foreign trade level.

\section{3) Harbor condition}

Harbor condition is the most basic factor in the development of harbor industrial district, which is a very important part of the harbor industrial district development potential evaluation. It mainly includes the port throughput capacity, port and port behind the land use condition. Harbor capacity is also called harbor traffic capacity, it is the greatest number of a port in a certain period (year, month, day) for the ship loading and unloading of goods can achieve, under the certain condition of technical equipment and labor organization, according to the reasonable operation process and advanced techniques. Harbor capacity is the maximum throughput in tons. It is the sum of all berth throughput capacity of the harbor. It mainly includes two aspects: the port container throughput, port cargo throughput.

Harbor construction condition is one of the important indexes of harbor industrial district development potential. If a harbor wants to become a national or even international harbor, it should have the ability of berthing 10 or even 20 tons vessels. This requires a long deep-water coastline. Therefore, the length of the deep-water coastline is a necessary factor of the harbor construction condition. Harbor reserve land condition is the supporting harbor condition to measure the harbor industrial district industry development situation and potential. The higher utilization level of harbor reserve land shows the better current situation of port development. The more Harbor reserve land shows the greater potential of port development. Therefore, harbor reserve land condition is also an important factor of harbor condition to consider.

\section{HARBOR INDUSTRIAL DISTRICT DEVELOPMENT POTENTIAL EVALUATION}

\section{A. Development potential evaluation process}

This study uses the analytic hierarchy process (AHP) to analyze the development potential of harbor industrial district, the specific steps are as follows:

1) Establish the hierarchy model of the determine factors and evaluation index.

According to the established determine factors and evaluation index of the harbor industrial district development potential evaluation, we established the hierarchy model of the determine factors and evaluation index. Target layer A, criterion layer B, index layer $\mathrm{C}$ and their relationship as shown in Fig. 1. 


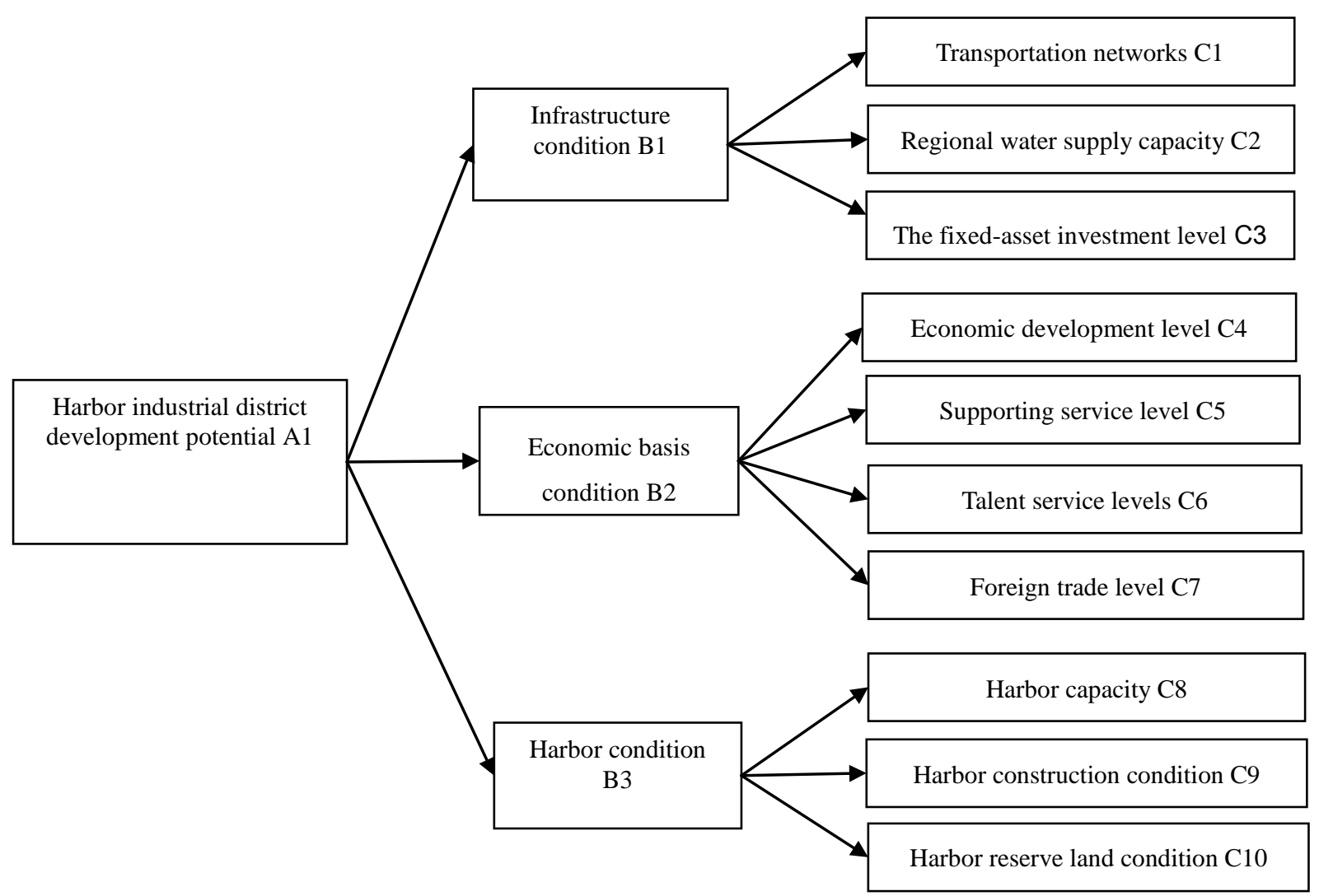

Fig.1. The harbor industrial districts development potential hierarchical chart

\section{2) Establish the judgment matrix}

According to the above hierarchical chart, combine the datum and expert opinion from universities and research institutes of regional economy, regional economic geography and industrial economy. By comparing the importance of the indexes, establish the judgment matrix hierarchically, and calculate the weight $\mathrm{W}$, the largest eigenvalue $\lambda$ max, the consistency index CI, and the consistency index ratio CR of each level single sort. As shown in the following Table IV to VII.

Here is the scale method: combine the previous research, the latest statistics, as well as the opinions of the experts in a comprehensive measure system. Use value 1, 2, 3, 4, 5, 6, 7, 8, 9 to measure the importance of certain element compared to the previous element. The value is bigger, the element is more important than the previous element.

When calculate the maximum eigenvalue of all levels and their corresponding eigenvectors, the eigenvector is the weight vector of corresponding to the index. Calculate the coincidence indicator $\mathrm{CR}$ according to the maximum characteristic root, and perform a consistency check to the judgment matrix. If CR $<0.1$, the consistency check is inerrant, otherwise, the result is not satisfied. In this case, we need to determine the judgment matrix again until satisfied.

TABLE IV. TARGET LAYER MATRIX A - B

\begin{tabular}{|c|c|c|c|c|c|}
\hline A & B1 & B2 & B3 & W & \\
\hline B1 & 1 & 3 & $1 / 3$ & 0.26 & $\lambda \max =3.04$ \\
B2 & $1 / 3$ & 1 & $1 / 5$ & 0.10 & CI $=0.02$ \\
B3 & 3 & 5 & 1 & 0.64 & CR $=0.03<0.1$ \\
\hline
\end{tabular}

TABLE V. TARgET LAYER MATRIX B1-C

\begin{tabular}{|c|c|c|c|c|c|}
\hline B1 & C1 & C2 & C3 & W & \\
\hline C1 & 1 & 2 & 3 & 0.53 & $\lambda$ (max $=3.05$ \\
\cline { 1 - 4 } C2 & $1 / 2$ & 1 & 3 & 0.33 & CI 0.03 \\
\hline C3 & $1 / 3$ & $1 / 3$ & 1 & 0.14 & CR $=0.05<0.1$ \\
\hline
\end{tabular}

TABLE VI. TARgET LAYER MATRIX B2-C

\begin{tabular}{|c|c|c|c|c|c|c|}
\hline B2 & C4 & C5 & C6 & C7 & W & \\
\cline { 1 - 6 } C4 & 1 & 4 & 5 & 3 & 0.54 & \multirow{2}{*}{$\lambda \max =4.19$} \\
\cline { 1 - 5 } C5 & $1 / 4$ & 1 & 3 & $1 / 3$ & 0.14 & CI $=0.06$ \\
C6 & $1 / 5$ & $1 / 3$ & 3 & 1 & 0.07 & \multirow{2}{*}{ CR $=0.07<0.1$} \\
\hline C7 & $1 / 3$ & 3 & 3 & & & \\
\hline
\end{tabular}


TABLE VII. TARget LAYER MATRIX B3-C

\begin{tabular}{|c|c|c|c|c|c|}
\hline B3 & C8 & C9 & C10 & $\mathbf{W}$ & \\
\hline C8 & 1 & $1 / 3$ & $1 / 2$ & 0.16 & $\lambda \max =3.01$ \\
\hline C9 & 3 & 1 & 2 & 0.54 & $\mathrm{CI}=0.01$ \\
\hline C10 & 2 & $1 / 2$ & 1 & 0.30 & $\mathrm{CR}=0.01<0.1$ \\
\hline
\end{tabular}

By the data in the table above, the judgment matrix established satisfy the consistency.

3) Calculate the index weight

To the relative weight of each index in index layer $\mathrm{C}$ multiplied by the weight of its corresponding criterion layer $\mathrm{B}$ in order to obtains the total weight of the index in the evaluation system. The calculation results are shown in table VIII below. the table shows that, in the development potential evaluation indexes of harbor industrial districts, the weight in the top three is respectively $\mathrm{C} 9, \mathrm{C} 10, \mathrm{C} 1$, corresponding to harbor construction condition, harbor reserve land condition and the transportation network respectively. This shows that, a good harbor industrial development must rely on the appropriate harbor condition, and supported by the perfect inside and outside traffic network, combined with other factors such as regional water supply capacity and supporting service level.
According to the size of development potential, we can get a score of each harbor industrial district, the score range from 1 to 5. "1" represents the development potential is small, "2" represents the development potential is ordinary, "3" represents the development potential is medium, "4" represents the development potential is big, " 5 " represents the development potential is huge. The value between them represents the degree between two development potential. Such as 3.5 represents the development potential is between the medium big. According to the level of total sorting weight table, combining the ten factors score of different harbors from expert of regional economy, regional economic geography and industrial economy in universities and research institutes. We can obtain the weighted score of various factors, so as to obtain comprehensive weighted value of each harbor, as shown in the following table.

TABLE VIII. The Harbor Industrial District DeVelopment Potential EVAluation Elaborate Index Total Sports

\begin{tabular}{|c|c|c|c|c|c|}
\hline \multirow{2}{*}{ index } & B1 & B2 & B3 & \multirow{2}{*}{ W } & $\begin{array}{c}\text { Order of } \\
\text { importance }\end{array}$ \\
\cline { 2 - 4 } & 0.26 & 0.10 & 0.64 & 0.138 & 3 \\
\hline C1 & 0.53 & 0 & 0 & 0.086 & 5 \\
\hline C2 & 0.33 & 0 & 0 & 0.036 & 7 \\
\hline C3 & 0.14 & 0 & 0 & 0.054 & 6 \\
\hline C4 & 0 & 0.54 & 0 & 0.014 & 9 \\
\hline C5 & 0 & 0.14 & 0 & 0.007 & 10 \\
\hline C6 & 0 & 0.07 & 0 & 0.025 & 8 \\
\hline C7 & 0 & 0.25 & 0 & 0.102 & 4 \\
\hline C8 & 0 & 0 & 0.16 & 0.346 & 1 \\
\hline C10 & 0 & 0 & 0.54 & 0.192 & 2 \\
\hline
\end{tabular}

TABle IX. The Development Potential Sorting TABle of Harbor Industrial Districts of Zhejiang Province

\begin{tabular}{|c|c|c|c|c|c|c|c|c|c|c|c|}
\hline \multirow[t]{2}{*}{ Index } & \multirow[t]{2}{*}{$\mathbf{W}$} & \multicolumn{2}{|c|}{$\begin{array}{l}\text { Jiaxing harbor } \\
\text { industrial district }\end{array}$} & \multicolumn{2}{|c|}{$\begin{array}{l}\text { Ningbo harbor } \\
\text { industrial district }\end{array}$} & \multicolumn{2}{|c|}{$\begin{array}{l}\text { Zhoushan harbor } \\
\text { industrial district }\end{array}$} & \multicolumn{2}{|c|}{$\begin{array}{c}\text { Circum-Sanmen- } \\
\text { Bay-taizhou-bay } \\
\text { harbor industrial } \\
\text { district }\end{array}$} & \multicolumn{2}{|c|}{$\begin{array}{c}\text { Circum-Yueqing- } \\
\text { Bay-Wenzhou-bay } \\
\text { harbor industrial } \\
\text { district }\end{array}$} \\
\hline & & Score & $\begin{array}{c}\text { Weighted } \\
\text { score }\end{array}$ & Score & $\begin{array}{c}\text { Weighted } \\
\text { score }\end{array}$ & Score & $\begin{array}{l}\text { Weighted } \\
\text { score }\end{array}$ & Score & $\begin{array}{l}\text { Weighted } \\
\text { score }\end{array}$ & Score & $\begin{array}{c}\text { Weighted } \\
\text { score }\end{array}$ \\
\hline $\begin{array}{c}\text { Infrastructure condition } \\
\text { B1 } \\
\end{array}$ & 0.26 & \multicolumn{2}{|r|}{0.96} & \multicolumn{2}{|r|}{1.05} & \multicolumn{2}{|c|}{0.71} & \multicolumn{2}{|c|}{0.81} & \multicolumn{2}{|c|}{0.9} \\
\hline $\begin{array}{l}\text { Transportation networks } \\
\text { C1 }\end{array}$ & 0.138 & 3.75 & 0.52 & 3.92 & 0.54 & 2.58 & 0.36 & 3.08 & 0.42 & 3.42 & 0.47 \\
\hline $\begin{array}{c}\text { Regional water supply } \\
\text { capacity C2 }\end{array}$ & 0.086 & 3.67 & 0.31 & 4.25 & 0.36 & 3.00 & 0.26 & 3.25 & 0.28 & 3.58 & 0.31 \\
\hline $\begin{array}{c}\text { The fixed-asset } \\
\text { investment level C3 }\end{array}$ & 0.036 & 3.67 & 0.13 & 4.17 & 0.15 & 2.58 & 0.09 & 3.08 & 0.11 & 3.42 & 0.12 \\
\hline $\begin{array}{c}\text { Economic basis } \\
\text { condition B2 }\end{array}$ & 0.10 & \multicolumn{2}{|c|}{0.38} & \multicolumn{2}{|l|}{0.42} & \multicolumn{2}{|c|}{0.28} & \multicolumn{2}{|c|}{0.34} & \multicolumn{2}{|c|}{0.33} \\
\hline $\begin{array}{c}\text { Economic development } \\
\text { level C4 }\end{array}$ & 0.054 & 3.75 & 0.20 & 4.17 & 0.23 & 2.92 & 0.16 & 3.42 & 0.18 & 3.42 & 0.18 \\
\hline $\begin{array}{l}\text { Supporting service level } \\
\text { C5 }\end{array}$ & 0.014 & 3.83 & 0.05 & 4.00 & 0.06 & 2.75 & 0.04 & 3.50 & 0.05 & 3.17 & 0.04 \\
\hline Talent service levels C6 & 0.007 & 3.67 & 0.03 & 4.33 & 0.03 & 2.75 & 0.02 & 3.67 & 0.03 & 3.50 & 0.02 \\
\hline Foreign trade level C7 & 0.025 & 3.83 & 0.10 & 4.17 & 0.10 & 2.58 & 0.06 & 3.17 & 0.08 & 3.58 & 0.09 \\
\hline Harbor condition B3 & 0.64 & \multicolumn{2}{|c|}{1.96} & \multicolumn{2}{|c|}{2.49} & \multicolumn{2}{|c|}{2.44} & \multicolumn{2}{|c|}{2.02} & \multicolumn{2}{|c|}{2.23} \\
\hline Harbor capacity C8 & 0.102 & 3.00 & 0.31 & 4.08 & 0.42 & 3.92 & 0.40 & 3.00 & 0.31 & 3.42 & 0.35 \\
\hline $\begin{array}{l}\text { Harbor construction } \\
\text { condition C9 }\end{array}$ & 0.346 & 3.25 & 1.12 & 3.83 & 1.32 & 4.00 & 1.38 & 3.25 & 1.12 & 3.50 & 1.21 \\
\hline
\end{tabular}




\begin{tabular}{|c|c|c|c|c|c|c|c|c|c|c|c|}
\hline \multicolumn{12}{|c|}{ Cont. to TABLE IX } \\
\hline $\begin{array}{l}\text { Harbor reserve land } \\
\text { condition C10 }\end{array}$ & 0.192 & 2.75 & 0.53 & 3.92 & 0.75 & 3.42 & 0.66 & 3.08 & 0.59 & 3.50 & 0.67 \\
\hline Total weighted score & & \multicolumn{2}{|c|}{3.30} & \multicolumn{2}{|c|}{3.97} & \multicolumn{2}{|c|}{3.43} & \multicolumn{2}{|c|}{3.18} & \multicolumn{2}{|c|}{3.48} \\
\hline Ranking & & \multicolumn{2}{|c|}{4} & \multicolumn{2}{|c|}{1} & \multicolumn{2}{|c|}{3} & \multicolumn{2}{|c|}{5} & \multicolumn{2}{|c|}{2} \\
\hline
\end{tabular}

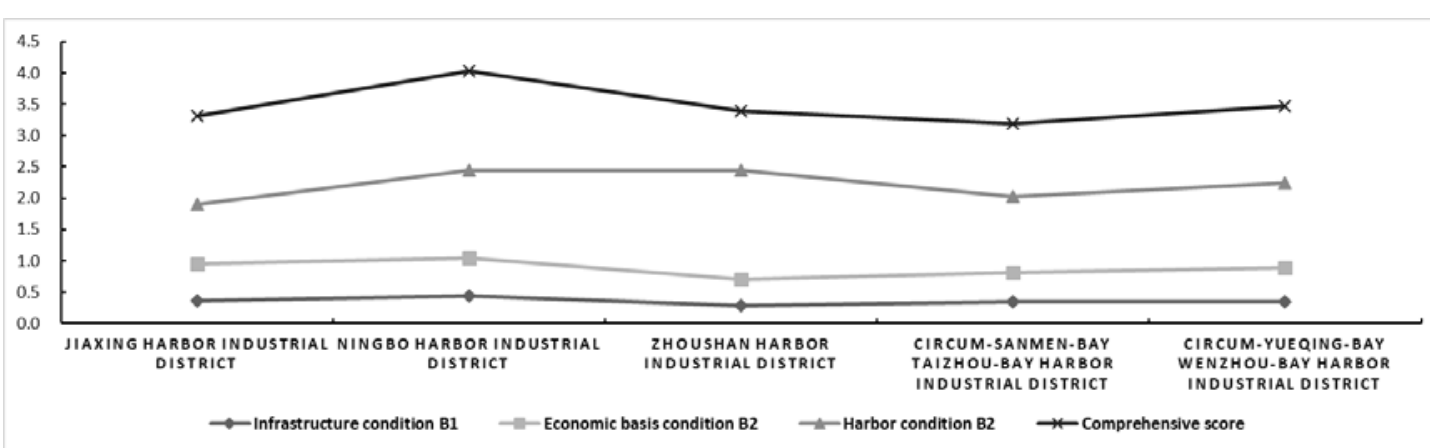

Fig.2. The comparison of harbor industrial districts development potential

\section{CONCLUSION}

\section{A. The index conclusion of harbor industrial district}

According to the analysis of indicators above, there are advantages and disadvantages of each harbor industrial district in Zhejiang province. The comprehensive weighted score of Ningbo harbor industrial district is 3.97 , which is close to 4, indicates that Ningbo harbor industrial district has great development potential in harbor industrial districts. And it ranks first in several port areas in Zhejiang Province, all the elements integrated, which shows Ningbo harbor industrial district has the greatest potential for development. The comprehensive weighted score of Circum-Yueqing-bay-Wenzhou-bay harbor industrial district is 3.48 , which is in the second place comparing with other harbor industrial districts. The comprehensive weighted score of Zhoushan harbor industrial district is 3.43, ranks the third, which is lower than lower than Ningbo harbor industrial district and Wenzhou harbor industrial district. The comprehensive weighted score of Jiaxing harbor industrial district is 3.3, which is in the fourth place, higher than the Circum-Sanmen-bay-Taizhou-bay harbor industrial district. Compared the weighted score of each index, the score of Jiaxing harbor industrial district generally belong to the middle level. But the score of harbor reserve land condition is the lowest. The comprehensive weighted score of Circum-Sanmen-bay-Taizhou-bay harbor industrial district is 3.18, which is in the last place comparing with other harbor industrial districts.

\section{B. The potential analysis of harbor industrial district}

All the indicators of Ningbo harbor industrial districts are relatively higher, especially in the harbor capacity and the transportation networks. But in the harbor construction condition, Ningbo harbor industrial district is slightly weaker than Zhoushan harbor industrial district, mainly due to the fact that the deep-water coastline in Ningbo is almost occupied, but the natural deep-water coastline of Zhoushan harbor industrial district is relatively abundant, which is unmatched by other harbor industrial districts.
Compared with other harbor industrial districts, Zhoushan harbor industrial district ranks last in the transportation networks, regional water supply capacity, the level of investment in fixed assets and the foreign trade contact level, but is prominent in the harbor capacity and harbor construction condition which indicate that the regional economy and infrastructure investment of Zhoushan harbor industrial district is relatively weak in the province's port area, but the harbor condition is very good, so Zhoushan harbor industrial district has great potentials.

Ningbo harbor and Zhoushan harbor were merged into the same harbor in 2005, Ningbo harbor industrial district just makes up for the weakness of Zhoushan harbor industrial district. So, the Ningbo-Zhoushan harbor industrial district is very promising and will also be more competitive internationally in the future.

Compared with other harbor industrial districts, the weighted score of economic development level and supporting service level are low at Circum-Yueqing-bay- Wenzhou-bay harbor industrial district. But the harbor construction condition and harbor reserve land condition of Circum-Yueqing-bayWenzhou-bay harbor industrial district are above the average, which indicate Circum-Yueqing-bay-Wenzhou-bay harbor industrial district has huge potential to develop. With the rapid development of economy, the coastal infrastructure conditions improve gradually, and will lead to a stage of rapid growth in the future.

In the future, harbor reserve land condition will mainly limit the development of Jiaxing harbor industrial district. Although there are abundant coastal shoal resources in Jiaxing, how to provide enough industrial land for the expansion of Jiaxing harbor industrial district expanding is the main problem in the future development of Jiaxing harbor industrial district.

The low potential of industrial development at Circum-Sanmen-bay-Taizhou-bay harbor industrial district is mainly due to low weighted score of the harbor construction condition and low transportation networks. So, we can conclude that the lack of natural deep- water coastline and the imperfection of the coastal traffic facilities lead to low 
development potential of Circum-Sanmen-bay- Taizhou-bay harbor industrial district.

In conclusion, the harbor area should be based on its own location factors, economic base, resource factors, and policy factors to choose their own harbor industry development model. On this basis, by adjusting the harbor area industrial structure, space structure, technology structure and resource utilization way for upgrading of harbor-vicinity industry. Through the development of harbor-vicinity industry, the harbor and the whole area also will be developed [4]. At the same time, we also should pay attention to the protection of the environment under the guidance of the concept of sustainable development, by use of technical innovation, system innovation, industrial transformation, new energy development and other means. To reduce the high carbon energy consumption coal oil and greenhouse gas emissions as much as possible. The port industry in the blue economic zone should be built into a low carbon economy demonstration zone, which requires that it should take into account environmental protection while economy develops [5].

\section{REFERENCES}

[1] Dong, C, 2005. Study of Development Strategy of Tianjin Harbor industrial district [D], Tianjin University.

[2] Wang, L and Xu, S.1990. Introduction of analytic hierarchy process[M], China Renmin University Press.

[3] Fang, C and Mao H.1999. A System of Indicators for Regional Development Planning. Acta Geographica Sinica, 54(5):410-419.

[4] Zhai, W. et al., 2006. Land Intensive Use in City Development Zones Based on Analytic Hierarchy Process: A Case Study of Jiangsu Province. Journal of Nanjing University (Natural Sciences) ,42(1):96-102.

[5] Sun,Q,2007. Thoughts and Suggestions on the development of Marine economy in Shandong province [J]. Macroeconomic Management (4):58-62.

[6] Dai,X,2007. Circular economy promotes sustainable development of liaoning Marine economy [J]. Port Economy,(3)50-52. 